\title{
The Motoring Lobby in New Zealand, 1898-1930
}

\author{
AUSTIN GEE AND ALEXANDER TRAPEZNIK
}

\begin{abstract}
This article examines how motoring organisations in New Zealand sought to influence local and national government during the first three decades of their existence. It shows that motor clubs formed alliances with other pressure groups which changed according to the issues at stake. These allies included local government bodies, urban and provincial promotional leagues, chambers of commerce, tourist organisations and representatives of other road users. Automobile associations sought to gain a favourable public image for motoring through the press, both through newspapers and their own publications, as well as by self-policing and charitable activity. This article looks at the lobbying of parliamentarians regarding legislative measures that affected motorists such as roading, taxation and regulation. It concludes that motoring organisations' demands in general received a favourable response so long as there were no major implications for government revenue.
\end{abstract}

Early New Zealand motorists exerted influence on local and national government largely by means of their clubs and associations. It was not, however, a straightforward case of a small, wealthy interest group pursuing its own interests; rather, the first decades of motoring show a complex picture of shifting alliances. Motor clubs, in order to achieve their aims of promoting motoring and the interests of motorists, formed ad hoc arrangements with other organisations that varied according to the circumstances and the issue at stake. These organisations included local government bodies, urban and provincial promotional leagues, chambers of commerce, tourist organisations, commercial vehicle operators, cycling clubs and motor sports clubs, among others. Apart from coachbuilding, there was no local motor vehicle manufacturing industry, but, by the end of the First World War, motor traders and garage proprietors had formed their own organisations. Importers and dealers were typically small local businesses, and they also exerted influence through the motor clubs. This article looks at how motoring organisations dealt with questions of policing, publicity, roading, legislation, taxation and regulation. They were relatively powerless before 1914, but by the 1920 s played a significant role in helping frame local regulations and national legislation affecting motorists. In a significant concession by the state, from 1924 motoring organisations were represented on the Main Highways Board, which was responsible for allocating government funds for road construction. They were soon able to claim to "have more than justified their existence. They have watched affairs on behalf of the motorists . . . and have by persuasion or agitation had many anomalies removed, and many wrongs righted. They have . . . helped in the promotion of beneficial legislation for motorists, and ... have helped the local authorities to keep abreast of the times." 1

The historiography of motoring in New Zealand is relatively undeveloped. The best survey of the social history of transport in general is James Watson's Links: A History of Transport and New Zealand Society. ${ }^{2}$ John McCrystal's 100 Years of Motoring in New Zealand considers the activities of automobile associations, but, in general, little use has been made of the records of the provincial motor clubs. ${ }^{3}$ This article examines the work of some of these organisations in the context of wider pressure group activity. The pioneering work internationally on the political role of motorists is William Plowden's The Motor Car and Politics, 1896-1970. 
There is no equivalent to this study for New Zealand, so this article is intended as a preliminary exploration of the topic. It leaves aside for future study the topics of road safety and insurance, both major concerns of all the motoring organisations. Instead, this article focuses on questions of regulation, taxation, road construction and the environment, concluding that it was the shifting alliances formed by motorists' associations that made them effective.

\section{Membership and Activities}

Though New Zealand's first motor car was imported only in 1898, and there were no local manufacturers, within a quarter of a century the country had one of the highest levels of car ownership worldwide. In 1907 it was estimated there were about 3,000 private cars in the country, or one for every 316 people. ${ }^{5}$ In the second decade of the century car ownership grew markedly as a result of the availability of cheaper and more practical vehicles, not least the Ford Model T, and the development of a second-hand market for cars. ${ }^{6}$ Accurate figures are first available for 1925, by which time there were 71,403 cars, or one for every 19 people; a decade later, despite the effects of the Depression, the ratio had reached one in $12 .{ }^{7}$ In comparison, Australia had ratios of 1:13.8 in 1925 and 1:7.5 by $1935 .{ }^{8}$ The United States had almost 90 percent of the world's cars in 1924, equal to one car for every 7 people, ${ }^{9}$ and by 1935 this had reached 1:5.6. ${ }^{10}$ Canada came a close second, ${ }^{11}$ and other wealthy countries where purchasing power was not so widely spread, such as France and Britain, had car ownership ratios by the mid-1930s of 1:24.5 and 1:30.6 respectively; the world average was 1:66. ${ }^{12}$

Regional motor clubs were formed throughout New Zealand from 1903 onwards. By 1915 there were 11 of them, and by 1928, 15. They varied widely in size, from the large Auckland and Canterbury associations to the smaller Nelson and Wairarapa clubs. ${ }^{13}$ Some of them briefly sought to exclude members of the motor trade, but in general they sought to attract as wide a membership as possible. ${ }^{14}$ In most cases, they incorporated motorcyclists: in the earliest years, both car drivers and motorcycle riders were referred to indiscriminately as "motorists." From the incomplete figures available, it seems that motoring organisations rarely represented more than a quarter of all motorists. Early local authority vehicle registration records survive only patchily, but of the 175 owners of cars registered in Dunedin in 1911, only 35-a fifth-had joined the Otago Motor Association by the following year. ${ }^{15}$ Matters seem not to have improved substantially by 1927 , when the Southland Motor Association estimated that its membership constituted only about a quarter of all car owners in its province. ${ }^{16}$ By the end of 1934, the Otago club's membership had reached 2,651, representing about 22 percent of the approximately 12,000 cars registered in the province. ${ }^{17}$ The organisations were naturally open to accusations they did not represent the views of motorists in general. ${ }^{18}$

Little analysis has been conducted of the membership of motoring clubs in this period. However, the Otago Motor Club (OMC) membership records for 1909-15 show that much the largest group of car owners who joined comprised business owners or partners: 17 percent of all private and commercial members. A further 10 percent were managing directors, general managers or simply managers of businesses in Dunedin. Runholders or large farmers represented 11 percent of OMC members, some of them with city residences. The street directories provide no profession for 3.4 percent of the club's members, generally a sign of a retired businessman or farmer. Members of the rapidly growing motor trade - agents, garages, professional drivers - were unsurprisingly among the earliest to own cars in large numbers: they formed 9 percent of the membership of the OMC. Men with a professional interest in the new technology could be expected to be among the early adopters of motor cars: engineers, both mechanical and electrical, represented 3.4 percent of the total. All other urban professions 
were represented in only small numbers among early car owners. For instance, only three architects owned cars and belonged to the OMC; they, however, represented a quarter of all architects working in the city in 1914. The four prominent Dunedin publishers and booksellers who ran cars represented about 12 percent of their profession. Yet the two wealthy butchers accounted for a mere 5 percent of their brethren, and the four pioneering motorist builders just 2 percent of the trade. Perhaps more surprisingly, the 8 lawyer members of the OMC represented only about 9 percent of local members of the legal profession. Women comprised 4.4 percent of OMC members, which appears typical of other comparable countries. These figures are close to those for the motorists who registered their cars in 1911 but had not joined the OMC within a year. Distance from Dunedin rather than profession appears to have been the reason for not joining: 17 percent of them were farmers. ${ }^{19}$

From the outset, the motor clubs cooperated with one another on matters of common interest. They provided information and advice, sometimes sending visiting speakers. There was no single national organisation representing motorists until $1991,{ }^{20}$ but the New Zealand Automobile Association, an umbrella organisation, had been formed in 1907. Feeling that North Island concerns predominated, several South Island clubs seceded to form their own motor union in 1920; its northern counterpart was formed in $1928 .{ }^{21}$ In 1925 the South Island Motor Union (SIMU) had 7,250 members, representing just over a quarter of the island's 27,480 registered cars. ${ }^{22}$

Though they had a clear political agenda and several of them adopted the name "automobile association," the New Zealand motor clubs were not campaigning organisations on the model of the Automobile Association (AA) in Britain. This had been formed in 1905 to take direct action against police speed traps and other forms of what it saw as official harassment of motorists. ${ }^{23}$ Speed traps did not become anything like such a controversial issue in New Zealand. They seem not to have been so frequently employed by the police - though race days were often targeted - and magistrates generally were not seen as unreasonably harsh on motoring offenders. ${ }^{24}$ On one occasion in 1925, a committee member of the Otago Motor Club stood in the middle of the road to warn fellow motorists of a nearby police speed trap. He was reported by a fellow club member and charged with obstructing the police. The magistrate rejected his defence that he merely sought to prevent the commission of an offence, lamented that the motor club had sanctioned his behaviour, and fined him $£ 10 .{ }^{25}$

Most motor clubs retained a lawyer and paid the legal expenses of their members in cases where a principle was seen to be at stake. ${ }^{26}$ Yet this ran the risk of appearing to the wider public as if they were closing ranks and condoning dangerous or antisocial behaviour. ${ }^{27}$ Club officials also lobbied government ministers on behalf of members who faced legal action. A delay in issuing a summons to a member of the Canterbury Automobile Association for speeding in 1913 prompted one such letter from the club's secretary to the Minister of Justice. The stipendiary magistrate concerned was obliged to provide a full explanation to the minister. ${ }^{28}$ Complaints from motoring organisations about prosecutions and sentencing, however, received the predictable response that the Minister of Justice could not intervene in the workings of the courts. $^{29}$

Motor clubs cooperated with the local authorities in policing dangerous driving by both their own members and other motorists. ${ }^{30}$ Clubs responded to complaints of dangerous driving on the part of their members by writing to reprimand them or, in more serious cases, calling them to account for their behaviour in person. While they might offer rewards for convictions, they 
often sought to settle matters without involving the police. ${ }^{31}$

\section{Tourism and Publicity}

Motor clubs sought to protect their members' interests through lobbying, self-regulation and self-policing, but some saw their main purpose as social. Newspapers gave attention, nearly always sympathetic, to public statements by motor clubs, both local and those well outside their own areas. The press reported local motor club committee meetings and activities in detail, commonly among their reports on sports clubs, even when no motor sport was involved. ${ }^{32}$ Motor clubs maintained good relations with sympathetic journalists. One of them, R. H. Stables of the Southland Times in Invercargill, was given a case of pipes and a goldmounted tobacco pouch by the local motor association when he left for a new job elsewhere. ${ }^{33}$ Some motoring activities were consciously seen as good for public relations, and much publicity was given to the outings organised by motor clubs, particularly before the First World War. From the outset, clubs put on regular runs to local beauty spots for social activities such as picnics and sports. In their early years, several clubs also organised regular long-distance reliability runs, though some disapproved of the competitive element. ${ }^{34}$ The Southland Motor Association, for instance, believed such runs were of benefit only to the motor trade, not to private motorists. ${ }^{35}$ Early motor races took place under the auspices of local motor clubs, but they did not seek to establish overall control of motor racing, as was for instance the case in Britain, where the Royal Automobile Club (RAC) acted as a governing body. ${ }^{36}$ In New Zealand, small local motor sports clubs exercised considerable autonomy. The social emphasis of the early motor clubs was more clearly evident in the motor gymkhanas held before the First World War. Intended to raise money for charity, and sometimes in collaboration with local social clubs such as the Otago Early Settlers' Association in Dunedin, these convivial events combined light-hearted driving competitions with prizes for the most attractively decorated vehicles. ${ }^{37}$ Motor clubs' charitable activities also included regular outings for large groups of orphans.

The division seen in several other countries between motor clubs and touring clubs did not develop in New Zealand. ${ }^{38}$ Though there was a great deal of variety among European clubs, in general there was a division between elitist automobile clubs, which were involved in motor sport, and the better-organised touring clubs, whose main purpose was to promote tourism, whether by car or other means, and were often sceptical of commercial motives. ${ }^{39}$ New Zealand motor clubs conformed more closely to the latter than the former pattern, leaving little space for separate touring organisations. However, a National Tourist League was formed in 1924 and, despite its small membership, was notably active and acquired some political influence. ${ }^{40}$ The league campaigned for improvements to scenic roads and for the provision of camping grounds for motor tourists, among a wide range of other causes; it appears to have folded in 1940. Regional promotion organisations with which the motor clubs had close links, such as the Southland League and the Otago Expansion League, also encouraged motor tourism. ${ }^{41}$ In large part, however, the relative insignificance of touring clubs was due to the existence of a government Department of Tourist and Health Resorts, established in 1901. Later renamed the Tourist and Publicity Department, it promoted scenic, sporting and health resorts both at home and abroad. It ran travel bureaux throughout New Zealand and had branches in Britain, the United States, Canada and Australia. The department ran its own resort hotels and health spas in scenic districts. By comparison, in the Australian state of Victoria, the government tourist bureau often referred enquiries to the state automobile club's own touring department. ${ }^{42}$

An important means of publicity adopted by most motoring organisations in the 1920s was 
provided by their periodical publications. Usually monthly, these were substantial publications; in some cases, they proved difficult to sustain, and folded during the depression of the early 1930s. The earliest motoring journals had been purely commercial enterprises, the most successful of them produced by Arthur Cleave, an Auckland periodical publisher and prominent early motorist. Founded about 1903, his New Zealand Motor and Cycle Journal claimed to be "the oldest wheel paper in the southern hemisphere." 43 The journals published by motor clubs contained a similarly wide range of motoring and technical news and advice, along with reports on car and motorcycle competitions, touring and holiday destinations. Some editors clearly found it a struggle to fill their pages; The Motorist, for one, resorted to short stories and serialised novels with no connection to motoring. Though they covered questions of motoring legislation, taxation and road construction, the majority of motor club periodicals steered clear of any overt political line. The major exception was New Zealand Motor Life, founded in 1925 as the official organ of the Auckland AA, but within a year it had become an independent, freelance publication dependent on advertising. ${ }^{44}$ Though there was no national motoring publication, regional motor club journals aimed at a wider readership.

\section{Relationships with Local Government}

Motor clubs had an obvious interest in the state of public roads and bridges, and so were in regular contact with urban and rural councils. They sought to avoid the implication of special pleading by arguing that remedying dangerous grades and bends, or cutting back overhanging vegetation, would benefit "all kinds of traffic," not just motor cars. ${ }^{45}$ Motorists involved in accidents were contacted by club officials in order to ascertain whether the state of the road was to blame. ${ }^{46}$ In the years following the First World War, motor clubs gathered information on road-building practices in New Zealand and other countries, which they provided to local councils. ${ }^{47}$ The Otago Motor Club, for instance, commissioned a civil engineer to examine examples of modern road building techniques elsewhere in New Zealand and published his report for wider distribution. ${ }^{48}$ An early attempt was made to form a "good roads" association in Christchurch in 1905, ${ }^{49}$ and one formed in Auckland by members of the regional automobile association in 1918 was more successful and long-lived. ${ }^{50}$ It had national influence and cooperated closely with motor clubs to pressure local and national government.

Motor clubs were often sufficiently well-funded to be able to back up their requests with offers of subsidies. The implication was clear that the improvements or repairs to roads and bridges they supported financially would be of direct benefit to the clubs' members, as well as to road users in general. Motor clubs provided rural councils with direction signs and warning notices free of charge. These were primarily of use to long-distance motorists who were unfamiliar with a locality. Members of motor clubs were not above occasionally contributing their own labour for road repair, though they made no explicit allusion to John Ruskin's ideas of the dignity of manual work, let alone his failed attempt at rural road-building by Oxford undergraduates. Nearly a hundred members of the Southland Motor Association laboured on the improvement of the six mile $(10 \mathrm{~km})$ road from the region's main city, Invercargill, to Oreti Beach, and a few years later on the road to the port town of Bluff, 14 miles $(22 \mathrm{~km})$ away. ${ }^{51}$ This sort of physical involvement by members of car clubs in road building was unusual internationally.

When clubs wished to influence local government decisions, whether on road building or traffic regulations, they often sent delegations to the city or county councils. The delegation that approached the Dunedin City Council in 1915, asking for "more equitable treatment between motors and other vehicles," was typical. ${ }^{52}$ To curry favour with local government politicians 
and officials, clubs sometimes invited them on official runs. The motorists were on their best behaviour: on one such outing from the city to a small seaside town in 1909, members of the Southland Motor Association were "particularly urged to abstain from racing on the road.",53 From early on, some councils consulted their local motor club regarding the provisions of bylaws. ${ }^{54}$ When lobbying failed to have the desired effect, motor clubs sometimes mounted legal challenges to local bylaws. These were funded by levying club members. When a tollgate was placed across the main highway south of Dunedin by a small rural council in 1915, to recoup the cost of road repairs, the local motor club raised $£ 75$ from its members to take the council to court. ${ }^{55}$ The council lost this test case, which attracted widespread attention.

\section{Relationships with National Government}

Motor clubs were well aware of the need to maintain the favour of the wider public. The First World War made the private car appear a symbol of unpatriotic luxury ${ }^{56}$ so the clubs did their best to preempt any criticism. Along with a wide range of clubs and societies, motoring organisations raised funds for patriotic purposes. Within weeks of war's outbreak, the Otago Motor Club raised $£ 274$ from among its members to pay for two cars to accompany the expeditionary force ${ }^{57}$ Members of the Nelson Motor-Cycle Club offered their services as local despatch riders. ${ }^{58}$ Even before the war, in 1909, a motor volunteer corps had been organised on the British model, at the suggestion of the Wellington Automobile Club. ${ }^{59}$ Motorists volunteered the use of their cars to transport army officers on manoeuvres. The scheme began badly, an officer dying in an accident caused by his drunken driver. ${ }^{60}$ By March 1915, however, the motor reserve comprised 133 officers who provided their own cars. ${ }^{61}$ As the war progressed, motor club members more generally helped transport convalescent soldiers and took them on sightseeing tours or trips to the theatre. One of the earliest complaints concerning drinking and driving arose from this activity, and concerned not the driver but the passengers: a military hospital complained to the Otago Motor Club that the alcohol given to its patients on motor outings was detrimental to their recovery. ${ }^{62}$

The first major political controversy to involve motor cars had arisen from their use at the general election of 1912. Though the hiring of carriages to convey voters to the polls was illegal, the use of free motor cars was not, and had an appealing novelty for many voters. ${ }^{63}$ Cars were seen as "now the most effectual weapon for electioneering," which gave an advantage to wealthier candidates. ${ }^{64}$ A member of the upper house, the Legislative Council, argued that "under existing conditions the motor-car is a determining element in many elections," so that in in effect the motor-car had itself been enfranchised with multiple votes. ${ }^{65}$ It was widely believed that the conservative opposition Reform Party had the advantage in hiring cars and borrowing them from its wealthy supporters. ${ }^{66}$ Motor clubs, however, appear to have been careful to retain their political neutrality by not lending cars to favoured candidates.

At the national level, motorists' organisations maintained close contact with the members of parliament for constituencies within their respective districts. They were frequently asked for information on proposed legislation likely to affect motorists, and pressed to use their influence to secure conditions favourable to motoring. For instance, when in 1914 changes to motor vehicle taxation were under consideration, the Otago Motor Club wrote to its local MPs asking them to obtain particulars of the proposed legislation, "and also to watch the interests of motorists in Otago." ${ }^{\prime} 7$ The minister in charge of the Bill was sent a list of formal recommendations by the club "as representing the Otago motorists," copies of which were sent to the local MPs along with a pamphlet on road construction. They were asked to "advise the 
other members as to our desires" and to "assist as far as possible in giving effect" to the club's recommendations. ${ }^{68}$ Such approaches were made only to those politicians with local connections and, unlike in some Australian states, MPs in general do not appear to have been circularised. ${ }^{69}$ In 1917, to demonstrate directly to MPs the poor state of Northland roads, the Auckland AA organised a large-scale motor tour of the region for them: 130 people were transported in 33 cars along exceptionally muddy tracks. ${ }^{70}$

When their interests coincided, motor clubs collaborated with other, nonmotoring special interest or pressure groups. One such was the Southland League, a promotional organisation for regional development which had a particularly close association with the Southland Motor Association. After the association folded shortly before the First World War, the league cooperated with the Otago Motor Club to push for improvements to a stretch of highway that linked their respective provinces, and solicited donations from other interested parties. ${ }^{71}$

\section{Politicians and Motorists}

Before the First World War, motorists were inclined to imply that resistance to their demands was based on ignorance of the benefits of motoring. Hostility to motor vehicles would fade, they believed, once those in influential positions acquired cars of their own. For instance, motorists campaigning in 1915 to have a rural road widened and fenced met strong resistance from local farmers. This was before motor vehicles became important for rural transport, and the ratepayers could see only disadvantages in the increased costs and wear caused by "pleasure" motoring. The car owners concluded that "it seemed that the only way to get the road opened would be to wait till the [farmers] had cars of their own and then they would change their minds." 72 Not even all politicians had direct experience of motoring at this time. In parliamentary debates, MPs would often refer to having been passengers in friends' or constituents' cars, and only a few had cars of their own. MPs' technical knowledge was limited, as was shown by one member's campaign in 1916 against the wartime importation of "German" cars from the United States. Pressed for an example, he named the Studebaker company. ${ }^{73}$ By the late 1920s, most MPs had cars, and debates on motoring questions were consequently much better informed, though still largely on an anecdotal level.

The attitude of local government toward motoring was to some extent determined by whether councillors were motorists themselves. The prominent motoring MP Thomas Hislop was also mayor of Wellington. There, he told MPs in 1906, "we get on all right, because, luckily, there are men on the Council who drive motor-cars." 74 Further north, in Wanganui, the mayor was also a motorist. He was jokingly accused in 1908 of keeping the streets in a "wavy-cum-bumpy condition" in order to aid his digestion when he took a drive after dinner. ${ }^{75}$ The mayor of the small southern town of Gore missed a council meeting in 1908 because he ran out of petrol. ${ }^{76}$ In general, however, few local politicians seem to have run motor cars before the war. In Dunedin, for instance, in 1914 the mayor did not have a car, official or otherwise. Of the 90 city and suburban borough councillors in office that year, only nine were members of the local motor club. Three of the 18 city councillors were members, as were the mayors of two small and relatively wealthy suburban boroughs. ${ }^{77}$

A decade later, the mayor of Dunedin had acquired a car but the senior council officers still had not. Amalgamation of suburban boroughs meant there were only 56 city and borough councillors in 1924, 17 of whom were members of the Otago Motor Club; only four of these were city councillors, the remainder representing the outer suburbs. No senior official of the city corporation yet belonged to the motor club, though they may have felt their office 
precluded joining such an organisation. ${ }^{78}$ Members of the city engineer's office, who had "a great deal of travelling to do," were, however, provided with an official car in $1917 .{ }^{79}$ Although probably no more than a quarter of Dunedin's car owners belonged to the Otago Motor Club, these figures indicate that in one of the country's wealthier, larger cities, the proportion of local politicians who owned cars rose from at least 10 percent in 1914 to 30 percent in 1924. The latter was about six times the rate of car ownership of the population in general.

\section{Effectiveness of Lobbying}

This level of familiarity with motoring on the part of members of local and national government affected how the motor clubs were viewed. Initially, their expert opinion was sought and their advice often adopted. But by 1920 the SIMU was complaining that there was "a tendency amongst some local bodies to pass bylaws with very detrimental effects to motorists, especially if none of the members own cars." They proposed as a solution that all bylaws affecting motorists should be submitted to the motor union before they were approved by the minister of internal affairs. ${ }^{80}$ This, unsurprisingly, was not taken up by the government.

In the course of the interwar years, motoring organisations were increasingly seen as special interest groups and their claims, accordingly, appear to have been treated more sceptically than in the early days of motoring. George Forbes, leader of the United Party who became Prime Minister in 1930, was unconvinced by some of the claims of the motoring lobby, despite being a member of the Canterbury Automobile Association of long standing. ${ }^{81}$ For instance, in that year he accused the MP Alfred Ansell, a former president of the Otago Motor Club, of taking "upon himself . . . the position of being champion of the motorists" and thinking "that because he is connected with an organization of motorists it is his duty to express the very narrow views held by some of them, as opposed to the interests of the country." 82 Even Sir Joseph Ward, an early parliamentary proponent of motoring, had become more wary by the late 1920s. When approached as Prime Minister in 1929 by a delegation on the question of funding the Main Highways Board, he "was very short and curt in his opening remarks, and gave the impression that he considered the Deputation was the result of political propaganda." His attitude softened when he recognised one of his constituents among the assembled representatives of the automobile associations, chambers of commerce, progress leagues and local government bodies. Once the Minister of Public Works intervened to correct a misapprehension, the Prime Minister gave "an opposite and entirely satisfactory answer" to the delegation's request. ${ }^{83}$

The effectiveness of political lobbying by motor clubs was uneven. Unlike in Britain and the larger Australian states, the basic legislation governing the use of motor cars predated the establishment of motoring organisations. The first New Zealand legislation to deal with private motor vehicles had a contentious passage through parliament in 1898. A private Bill was introduced by a Wellington importer in order to regularise the legal position of light selfpropelled road vehicles. The eponymous McLean Light Locomotives Bill attracted a great deal of criticism, not because it legalised the use of light motor vehicles on public roads but because its promoter sought the right to charge all car owners a fee to compensate him for the cost of introducing the legislation. ${ }^{84}$

In contrast, the Motor Cars Regulation Act of 1902 was uncontroversial. Motor cars were seen as symbols of modernity and progress, the acting Premier Sir Joseph Ward introducing the Bill by saying the "motor car has come to stay." 85 The inevitability of motor traffic was taken as given, and the debates were almost entirely concerned with speed restrictions in town and country and whether the regulation of motor vehicles was to be delegated to local authorities. 
Members of parliament were well informed of developments overseas, particularly in Britain and France. None, however, mentioned any direct personal experience of motor cars, or even knowing an owner of one. The general impression given by the debate was that cars were the coming thing and New Zealand needed to keep up with other advanced, modern countries: "it is no use hampering these cars in relation to their use and introduction into the colony." They would "sooner or later ... rule the road." The question of road maintenance and improvement to cope with motor traffic, which was soon to become the greatest public expense associated with motoring, was not considered in 1902, though the potential for damage to bridges was anticipated. ${ }^{86}$

Though the first motor clubs were formed from 1903 onwards, they appear to have had little influence on the framing of either the Motor Registration Bill of 1905 or the subsequent Motor Regulation Act of 1906. Like contemporary legislation in Victoria, the provisions of the 1905 Bill were based upon the existing British Motor Car Act of $1903 .{ }^{87}$ In several Australian states, the automobile associations actively opposed the introduction of legislation regulating motor vehicles in 1904-06. ${ }^{88}$ As in 1902, no New Zealand MP mentioned in the course of the debates owning a car personally, though by this time all had now encountered them on the road and several of them readily recounted anecdotes of bad behaviour by car drivers. The independent conservative MP who introduced the Bill, Charles Lewis, argued that motor registration was needed because cars posed a danger to public safety and their drivers were difficult to identify. He claimed motoring "had attracted a small minority of adherents whose idea of sport led them to indulge in acts which excited the resentment of the public," the motorised equivalents of "the bent-backed bounder who buckets along on a bike." Lewis, not a car owner himself, assured his colleagues that he had spoken to several motorists in his constituency who had "heartily approved of something being done to keep in check those who would bring motoring into disrepute." ${ }^{\prime 9} \mathrm{He}$ had promoted the legislation at the request of a number of local bodies in Canterbury. ${ }^{90}$

The government-sponsored Motor Regulation Act of 1906 consolidated and replaced the existing legislation. It was introduced specifically in response to requests from local bodies for some uniformity in the regulations concerning motor cars. Unlike the British legislation, no provision was made for a national speed limit on the grounds that it was difficult to detect and enforce. ${ }^{91}$ In this, New Zealand echoed the recommendation of the British Royal Commission on Motor Cars of $1906 .{ }^{92}$ Once again, the debate showed that few MPs had direct experience of motoring, but several knew of accidents or had witnessed near misses, contributing to a growing awareness of the danger posed by cars in urban streets. ${ }^{93}$

The newly appointed Liberal Prime Minister Sir Joseph Ward, though not a car owner himself, was favourably disposed to motor vehicles, which he saw as having great economic potential. He removed the duty on the importation of motor vehicles to assist people of moderate means to buy them for trade and business purposes. Ward argued in 1907 that if New Zealand had 20,000 cars instead of the approximately 3,000 at that time, they would produce a great deal of employment for mechanics and chauffeurs. He had to defend his policy against accusations that it favoured the wealthy almost entirely, and Ward made a clear distinction between the use of cars for business purposes and "pleasure" motoring; in practice, of course, the distinction was not so clear-cut. ${ }^{94}$ Lewis backed up this argument with examples of auctioneers, land agents, doctors and lawyers who had lately become reliant on motor cars for the success of their businesses: "The motor-car had really become a necessity for many." He announced he was even thinking of buying one himself. ${ }^{95}$ As in Australia, support for motoring crossed party 
and class lines; some Labour politicians saw motor vehicles as creating a demand for skilled employment. ${ }^{96}$

The de facto spokesman for motoring interests in parliament was the prominent Liberal lawyer and MP Thomas Wilford. Among his many sporting interests, he was a founding member of the Wellington Automobile Club, becoming its president in 1913-15. ${ }^{97}$ Wilford was a prominent member of the local harbour board and served as mayor of the city in 1910-11. He was MP for the northern suburbs, which were linked to the city by railway. The road alongside was improved at great expense as a result of Wilford's tireless campaigning. He had an advantage over other motoring MPs in that when he described local roads, his fellow members knew them from personal experience. Wilford's specialist knowledge allowed him to imply that the opinions of those who did not own cars were ill informed. ${ }^{98}$

Though the main outlines of the debate on regulating motor cars are familiar from other common-law jurisdictions, there were some notable differences. In Victoria, the provision in the 1909 Motor Car Act for the administration of motoring regulations by the police rather than local authorities has been interpreted as a manifestation of "law as technology," the provision for "scientific" government through regulation by state agencies. ${ }^{99}$ In contrast, in New Zealand, the main opposition to the 1906 legislation was on the grounds that it gave too much arbitrary power to individual policemen. One MP thought giving them the power to arrest errant motorists savoured more of tsarist Russia than New Zealand; the relevant clause was defeated. ${ }^{100}$

\section{Taxation and Roads}

Pressure on ministers or parliamentarians by motor clubs was not explicitly acknowledged until the First World War. When a tax on cars to pay for road repairs was proposed in 1913, the Minister of Public Works reported that it had been urged by "the owners of motor-cars," but he made no explicit mention of any motorists' association. ${ }^{101}$ On the day the Motor Bill of 1914 was due to be first debated, car and taxi owners deluged members of parliament with telegrams. ${ }^{102}$ This Bill was introduced to tax motor vehicles in order to fund road repair and bridge construction, but was quietly dropped when war broke out.

Taxation of motor vehicles was a major issue concerning motoring organisations both before and after the war. The government had planned to adopt the British system of graduated charging according to the nominal horsepower of the car's engine. Motorists' organisations and a conference of local authorities held in mid-1914 both favoured a tax on tyres instead as they believed it would more fairly reflect the extent to which a car used the roads, while being cheap and easy to collect. Wilford argued for a tyre tax, and claimed to be voicing the opinion of the principal car owners of the country. Borough and county councils, who had to fund road repairs but often received little revenue from car registration fees, also favoured the tax. ${ }^{103}$

Taxi owner-drivers, however, were opposed to the proposed tyre tax, as they foresaw themselves being taxed heavily to pay for the upkeep of rural roads they did not use, thereby effectively subsidising weekend "pleasure" motorists. Taxi drivers began to appear in significant numbers on membership lists of motor clubs during the war, and by the $1920 \mathrm{~s}$ a clear division had become evident between commercial users and private, "pleasure" motorists. ${ }^{104}$ The motor clubs took the side of the latter, causing members of the Taxi Owners' Association to declare they were "up against a pretty solid combination and the rich men of the country belong to the Automobile Union," who, "when they went on jaunts into the country, 
found out what the country roads were like and wanted them improved."105

Pressure on the government to deal with the problem of funding road repairs had grown in the later years of the war, led by motor clubs and local councils. Among them was the Otago Motor Association, which took the initiative in convening a meeting of delegates from nearly every local body in the province, who agreed that a tyre tax was the best option. A delegation of members of the North Island Automobile Association met the Minister of Public Works in 1919 to discuss the matter. They were accompanied by opposition Liberal MP Thomas Seddon, who subsequently introduced a Country Roads Bill that provided for a central roads board responsible for the main highways, ${ }^{106}$ following the British model that had also recently been adopted in Victoria. ${ }^{107}$ This was taken up by the government, which put forward a Motor Vehicles Bill in 1921. Introducing the legislation, the Minister of Internal Affairs said he had received a large number of letters from all over the country on the matter. Though there was general approval of the principle of taxing motor vehicle owners to pay for roads, there was much disagreement over how it was to be done. Some MPs suspected the government had been misled by the motor trade into improving country roads unnecessarily in order to encourage people to purchase cars for "joyriding" or pleasure motoring. Local bodies, represented by the Counties Association, had financial fears and favoured a tyre tax. ${ }^{108}$ Their opposition helped induce the government to drop the Bill and introduce revised legislation the following year.

The Main Highways Bill of 1922 was framed after consultation with the motorists' associations, local bodies and the Good Roads Association. ${ }^{109}$ Introducing the Bill, the minister for public works conceded that "there are those who will say that these people do not represent ratepayers and that they do not represent local authorities . . . but the motor associations of New Zealand have made very handsome contributions towards improving the roads and putting up signposts . . . and generally have shown a desire to assist." When it was pointed out that it was clearly in the motorists' interests to do so, the minister admitted he did "not think it has been from philanthropic motives, but when they give their time and get nothing for it they deserve commendation. They have right through been willing to help and do all they possibly could to bring about something which they regard as essential, and it appears to me that they have a just claim for representation." 110 One of the seven members of the Main Highways Board represented motoring interests, and two were nominated by the Counties Association. ${ }^{111}$ John Edie, who represented a rural electorate on the southern border of Dunedin, objected that whatever the motoring associations donated towards road maintenance, it would be a fraction of what rural counties would have to spend. The rural-urban divide was nowhere more obvious than where the two met: "As for the city people, all that they are concerned about is joy-riding, and it is the country people who are expected to maintain the roads for all this joy-riding." 112

The north-south divide was clear, too. The South Island motor clubs objected to the plan to institute, on the British model, a single roads board for both islands, as they could see most of its spending being in the North Island, which had the greatest need for road improvements. ${ }^{113}$ The SIMU exhorted its constituent motor associations to call meetings of representatives of counties, chambers of commerce, expansion and progress leagues, municipal councils and other interested bodies to consider the provisions of the proposed legislation. ${ }^{114}$ Despite their numerical strength and their exerting a great deal of pressure on the government, it took until 1929 before the southern motor clubs were able to secure a separate South Island main highways board. The southern motorists' representatives felt their treatment by the Minister of Public Works had been "very cavalier." 15 
New Zealand motoring organisations shared their British and United States counterparts' belief that government revenue from motoring sources should be spent only on roads and related infrastructure. Most attempts by American state governments to divert motoring revenue to other purposes were thwarted, but in Britain the first "raid" on the road fund took place in $1926 .{ }^{116}$ This made motoring organisations in New Zealand wary and when, three years later, the government, faced with reduced revenue, followed suit, its action prompted strong combined protests from motoring organisations, chambers of commerce and local authorities, which sent a delegation to discuss the matter with the Prime Minister. ${ }^{117}$ The diversion of funds from the Main Highways Board reversed the policy of the previous administration and was deemed to be "a distinct breach of faith with ratepayers and motorists," although this did not sway the government. ${ }^{118}$

The routine consultation of motoring organisations on proposed legislation was well established by 1924, when the centralised registration of motor vehicles was introduced. The Motor Vehicles Bill was "the outcome of a series of conferences" with motor associations and local bodies, and the Minister of Public Works declared it "the nearest we can get to giving something to fit in with the expression given at that time of the various interests." The Act's introduction of national vehicle registration came a decade after its provision in the abandoned 1914 legislation. ${ }^{119}$ But other issues remained open. Several motor clubs, for example, objected to the provision levying a tax on petrol, but without effect. The question of this means of funding road building and repair rumbled on for several years, and was widely discussed by chambers of commerce and local bodies as well as the motor clubs. ${ }^{120}$

\section{Conclusion}

When the early motoring lobby is examined in detail, it is clear that it comprised a series of shifting alliances between public bodies and private interest groups. Because of this, it is difficult to isolate the effectiveness of the motor clubs specifically. These alliances varied in their composition depending on the issue at stake, but typically the motor clubs were joined by regional promotion leagues, chambers of commerce and other professional bodies. Local government was often represented at the town, county and provincial levels. The initiative for action on matters affecting motorists could come from either local government or the motor clubs, either individually or coordinated by the motor unions. They applied pressure to the national government by such means as writing letters, sending telegrams, commissioning specialist reports and sending delegations to ministers in person. The example of Dunedin indicates that motorists were represented on local councils at a higher level than their numbers would warrant, but that even by the mid-1920s they were still far from the majority. Motoring lobbyists tended to succeed when their wishes coincided with the requirements of the authorities. The police were generally ready to accept the help of motor clubs in reporting motoring-related offences, and county councils to accept offers of subsidies for roads.

The formation of the two motor unions gave the motor clubs greater political and commercial influence. Though they did not gain everything they wanted, the motor unions were actively involved in the framing of the key legislation of the 1920s, and many of their principal demands were met by the Main Highways Act of 1922 and the Motor Vehicles Act of 1924. This contrasted with the motor clubs' limited influence on the national scale before 1914. Of course, campaigns by motor clubs, even when they attracted widespread public support, could still come to nothing if they were opposed to the government's own interests. Motorists' demands were much less likely to succeed at the national level if government revenue was at stake. For example, a long-running campaign against roadside advertising made very little impact on the 
government Railways Department, for which hoardings were an important source of income. Moreover, a single highways board was formed despite the determined opposition of southern motoring organisations, and even when a separate South Island board was eventually established, motorists were unable to prevent its revenue being diverted to general, non-roading purposes.

Motoring organisations were concerned to cultivate a positive public image, and did so by policing the behaviour of motorists, whether they were members or not. Clubs subsidised roadand bridge-building and repair where it was clear that motorists had at least in part created the need. On occasion, they even carried out some of the work themselves. A largely positive picture of motoring was promoted by newspapers and specialist magazines, and not just those published by the motor clubs themselves. Despite some scepticism, the attitude of many national politicians from the turn of the century onwards was that motor vehicles were the way of the future and New Zealand needed to keep up with international developments. Not for nothing did the small, young nation, on gaining Dominion status, choose as its motto "Onward." 121

\footnotetext{
${ }^{1}$ New Zealand Motor Life 1, no. 8 (20 August 1925): [1].

${ }^{2}$ James Watson, Links: A History of Transport and New Zealand Society (Wellington: GP Publications in association with the Ministry of Transport, 1996).

${ }^{3}$ John McCrystal, 100 Years of Motoring in New Zealand (Auckland: Hodder Moa Beckett, 2003); see for example Denis Le Cren, Celebrating 110 Years of the AA in Nelson 1904-2014 ([Nelson]: New Zealand Automobile Association Inc., 2014), and Tim Hyland, "A History of Motoring in Otago: With a Special Focus on the History of the Automobile Association Otago Incorporated (1905-1992)" ([Dunedin: Hocken Collections], 2012).

${ }^{4}$ William Plowden, The Motor Car and Politics, 1896-1970 (London: Bodley Head, 1971).

${ }^{5}$ New Zealand. Parliamentary Debates [NZPD] 140 (Wellington: Government Printer, 1907), 572, col. 2; calculated from "Census, 1906," in New Zealand Official Year-Book, 1908, www3.stats.govt.nz/New_Zealand_Official_Yearbooks/1908/NZOYB_1908.html ${ }^{6}$ The second-hand market is an under-researched topic, but by $1912-13,15.7$ percent of registrations were of second-hand cars, rising to 33.7 percent in 1913-14 (DCC TC33 1915 General M/2, W. G. Wickham, H. M. Trade Commissioner, Wellington, to Town Clerk, Dunedin, 23 February 1915). By 1915 , a second-hand car in good condition typically lost about a quarter of its value each year (Calculated from DCC CE2/2/9 Mot-Mc 1915-1918, City Engineer, Motor Car for Quarry Manager, 9 September [1915]).

${ }^{7}$ Calculated from "Motor-Vehicles Act," in New Zealand Official Year-Book, 1926: www3.stats.govt.nz/New_Zealand_Official_Yearbooks/1926/NZOYB_1926.html; "Registration of Motor-Vehicles," in New Zealand Official Year-Book, 1936, www3.stats.govt.nz/New Zealand Official Yearbooks/1936/NZOYB 1936.html. McCrystal, in 100 Years of Motoring (69), says New Zealand had the second-highest rate of car ownership after the United States with one motor vehicle for every 5.4 people by 1937. The number of heavy goods vehicles was growing at an even greater rate: the ratio of trucks to cars grew from 1:6.3 in 1925 to 1:3.6 in 1935.

${ }^{8}$ Calculated from Commonwealth Bureau of Census and Statistics, Official Year Book of the Commonwealth of Australia, No. 19-1926 ([Melbourne, 1926]) and No. 29-1936 (Canberra: Commonwealth Government Printer, [1936]). See also John William Knott, "Speed, Modernity and the Motor Car: The Making of the 1909 Motor Traffic Act in New South Wales," Australian Historical Studies 26, no. 103 (1994): 222, note 3; Knott, "The 'Conquering Car': Technology, Symbolism and the Motorisation of Australia before World War II," Australian Historical Studies 31, no. 114 (2000): 4, Figure 1.
} 
${ }^{9}$ Kerry Segrave, Parking Cars in America, 1910-1945: A History (Jefferson, NC: McFarland, 2012), 52 .

${ }^{10}$ L. J. K. Setright, Drive On! A Social History of the Motor Car (London: Granta, 2003), 84.

${ }^{11}$ The ratios for Ontario in 1929 and 1939 were 1:6.4 and 1:5.6 respectively (calculated from Gerald

T. Bloomfield, "No Parking Here to Corner: London [Ontario] Reshaped by the Automobile, 191161," Urban History Review 18, no. 2 (1989): 141.

${ }^{12}$ Setright, Drive On, 84. Setright provides no specific date for these figures; see also T. C. Barker, "The International History of Motor Transport," Journal of Contemporary History 20 (1985), 6.

${ }^{13}$ McCrystal, 100 Years of Motoring, 44-46.

${ }^{14}$ Hocken Collections, Dunedin, AG-760/1, Southland Motor Association [SMA] minute book, 15 December 1908; 23 December 1910.

${ }^{15}$ DCC TC33 1911 General M/2, List of Motor Vehicle Owners, 22 March 1911; Hocken 95-056-1/2, OMA Minutes From 13 January 1911 to 19 April 1912 [includes a register of members]; Toitu Otago Settlers Museum, AG-255, "Otago Motor Club List of Members season 1915/16." Similarly, 20 percent of local motorists belonged to the Southland Motor Association in 1912, according to "Stepney Wheel," a former member: "Motor Association," Southland Times [Invercargill], 30 September 1912, 2.

${ }^{16}$ Southland News [Invercargill], 23 May 1927.

17 "Better Motoring: Otago Association's Work," Evening Star [Dunedin], 25 September 1935, 13. The Official Year-Book for 1935 does not break down figures for vehicle registration by region.

${ }^{18}$ See for example "Number Plate Wrangle: Criticism and Reply," Evening Post [Wellington], 25 July $1925,17$.

${ }^{19}$ Calculated from DCC TC33 1909 General M/2, City of Dunedin Motor Car Registrations, 13 January 1908 [recte 1909]; DCC TC33 1911 General M/2, List of Motor Vehicle Owners, 22 March 1911; Hocken 95-056-1/2, OMA Minutes From 13 January 1911 to 19 April 1912 [includes a register of members]; Toitu Otago Settlers Museum, AG-255, "Otago Motor Club List of Members season 1915/16." The principal sources used to identify car owners were Stone's Otago and Southland Directories; the Otago Daily Times and Evening Star; military personnel files and probate records at Archives NZ; Southern People: A Dictionary of Otago Southland Biography, ed. Jane Thomson (Dunedin: Longacre in association with the Dunedin City Council, 1998); and The Cyclopedia of New Zealand, vol. 4: Otago and Southland Provincial Districts (Wellington: Cyclopedia Co., 1905).

${ }^{20}$ The result of a series of mergers of regional Automobile Associations during the 1980s; a national AA secretariat had been established in 1965.

${ }^{21}$ McCrystal, 100 Years of Motoring, 46.

22 "The Motor World," Otago Daily Times [Dunedin], 18 May 1925, 4; "Motor-Vehicles Act," in New Zealand Official Year-Book, 1926, www3.stats.govt.nz/New_Zealand_Official_Yearbooks/1926/NZOYB_1926.html

${ }^{23}$ Piers Brendon, The Motoring Century: The Story of the Royal Automobile Club (London: Bloomsbury, 1997), 10, 124; Plowden, The Motor Car and Politics, 97, 99, 105-06.

${ }^{24}$ The Autocar [London], 9 June 1906, quoted in Otago Witness [Dunedin], 15 August 1906, 54.

${ }^{25}$ NZ Truth [Wellington], 18 April 1925, 7.

${ }^{26}$ Le Cren, Celebrating 110 Years of the AA in Nelson, 35; see also Susan Priestley, The Crown of the Road: The Story of the RACV (South Melbourne: Macmillan, 1983), 22.

${ }^{27}$ See, for example, Anti-Road Hog [pseud.], "Reckless Motor Car Driving," Evening Star, 23 October 1908, 6 .

${ }^{28}$ Archives New Zealand, Wellington, J1 866 1913/536, E. Nordon, Secretary, Canterbury Automobile Association, to A. L. Herdman, Minister of Justice, 9 April 1913; Victor Grace Day, SM, to Minister of Justice, 12 April 1913.

${ }^{29}$ For example, Archives NZ J1 973 1920/194, J. G. Coates to W. Beauchamp Platts, Wellington, 24 February 1920.

${ }^{30}$ Hocken 95-056 77/1 Otago Motor Club [OMC] letter book, f. 35. Jas. Wm. Thomson, Secretary, to Inspector of Police, Dunedin, 11 November 1913. 
${ }^{31}$ For example: Hocken 95-056 77/1 OMC letter book, f. 46. Jas. Wm. Thomson, Secretary, to Head Master, Evansdale School, 18 November 1913.

${ }^{32}$ McCrystal, 100 Years of Motoring, 46.

${ }^{33}$ Southland Times [Invercargill], 28 November 1911, p. 5; see also Hocken 95-056 1/6 [OMC] minutes, 27 September 1919.

${ }^{34}$ McCrystal, 100 Years of Motoring, 51, 54.

${ }^{35}$ Hocken AG-760/1 SMA minute book, unidentified newspaper cutting "Southland Motor

Association" [Southland News (?), c. December 1910].

${ }^{36}$ Brendon, The Motoring Century, 10.

${ }^{37}$ Otago Witness, 4 March 1908, 37; Gijs Mom, Atlantic Automobilism: Emergence and Persistence of the Car, 1895-1940 (New York and Oxford: Berghahn, 2015), 85.

${ }^{38}$ See for example Melina Piglia, "Motor Clubs in the Public Arena: The Argentine Automobile Club, the Argentine Touring Club and the Construction of a National Roads System (1910-43)," Journal of Transport History 36, no. 2 (December 2015), 170-87.

${ }^{39}$ Mom, Atlantic Automobilism, 81.

${ }^{40}$ New Zealand Motor Life 5, no. 50 (20 February 1929), 29-30; NZPD 219 (1928), 588, col. 1.

${ }^{41}$ Southland Times, 5 May 1922.

${ }^{42}$ Priestley, Crown of the Road, 32.

${ }^{43}$ New Zealand Motor and Cycle Journal, new series 16, no. 210 (25 May 1920), 1. The journal survived until at least 1936.

${ }^{44}$ New Zealand Motor Life 2, no. 19 (20 July 1926), 1.

${ }^{45}$ Hocken 95-056 77/1 OMC letter book, f. 178, Jas. Wm. Thomson, Secretary, to The Clerk, Taieri County Council, Mosgiel, 8 June 1914.

${ }^{46}$ Hocken 95-056 77/1 OMC letter book, f. 218, Jas. Wm. Thomson, Secretary, to [J. J.] O'Kane, Dentist, Alexandra, 8 July 1914.

${ }^{47}$ Le Cren, Celebrating 110 Years of the AA in Nelson, 32.

${ }^{48}$ B. B. Couston, Modern Road Construction: Report on Auckland and Wellington Concrete Roads. Taranaki Tarred Roads ([Dunedin]: Otago Motor Club, 1919).

${ }^{49}$ Otago Daily Times, 19 September 1905, 5.

${ }^{50}$ New Zealand Herald [Auckland], 10 April 1918, 6.

${ }^{51}$ Hocken AG-760/2, SMA minute book, 83: Southland Motor Association. Annual Report. 30 April 1923. [printed sheet, 2]; 130 meeting Executive Committee, 24 May 1926.

${ }^{52}$ Hocken 95-056 77/1 OMC letter book, ff. 395-96. W. L. Colvin, Secretary, to Town Clerk, Dunedin, 19 February 1915.

${ }^{53}$ Hocken AG-760/1 SMA minute book, 9 January 1909.

${ }^{54}$ For example, the Taieri County Council in 1906: Otago Daily Times, 2 June 1906, 3; Dunedin City Council Archives, Taieri County Council miscellaneous documents Acc. 1906/106, Bye-Law Relating to Motor-Car Traffic in the Taieri County (Mosgiel, 1906).

${ }^{55}$ Hocken 95-056 77/1 A.10.16 OMC letter book, P. H. Power, Secretary [to members], 19 October 1915; Trapeznik and Gee, "Accommodating the motor car," 7; see also McCrystal, 100 Years of Motoring, 74.

${ }^{56}$ Plowden, The Motor Car and Politics, 110.

${ }^{57}$ Hocken 95-056 77/1 OMC letter book, f. 263, Jas. Wm. Thomson, Secretary, to Colonel [Arthur] Myers, [Motor Service Corps,] Wellington, 20 August 1914.

${ }^{58}$ NZPD 169 (1914), 498, col. 2.

${ }^{59}$ Archives NZ, AD1 558 D1909/1884, Claude M. Banks to Sir Joseph Ward, 19 May 1909.

${ }^{60}$ The Press [Christchurch], 5 November 1909, 9.

${ }^{61}$ Archives NZ, AD1 647 D1911/3120, Captain T. Hudson to Captain W. Beauchamp-Platts, Wellington, 5 March 1915, enclosing list of New Zealand Forces Motor Reserve of Officers.

${ }^{62}$ Hocken 95-056 1/6 [OMC] minutes, 12 August 1919.

${ }^{63}$ NZPD 154 (1911), 639, col. 2; see also Plowden, 265-66.

${ }^{64}$ NZPD 160 (1912), 593, col. 2; 819, col. 2.

${ }^{65}$ NZPD 163 (1913), 9, col. 1-2.

Journal of New Zealand Studies NS27 (2018), 130-146

https://doi.org/10.26686/jnzs.v0iNS27.5180 
${ }^{66}$ NZPD 157 (1912), 79, col. 2; 394, col. 1; 415, col. 1.

${ }^{67}$ Hocken 95-056 77/1 OMC letter book, ff. 202-03. Jas. Wm. Thomson, Secretary, to C. E. Statham [MP for Dunedin Central] and G. M. Thomson [MP for Dunedin North], Wellington, 1 July 1914.

${ }^{68}$ Hocken 95-056 77/1 OMC letter book, f. 233. Jas. Wm. Thomson, Secretary, to C. E. Statham, 23 July 1914; ff. 234-35. Jas. Wm. Thomson, Secretary, to H. D. Bell, Wellington, 23 July 1914.

${ }^{69}$ Kieran Tranter, “'The History of the Haste-Wagons': The Motor Car Act 1909 (Vic), Emergent Technology and the Call for Law," Melbourne University Law Review 29 (2005): 863-64.

${ }^{70}$ McCrystal, 100 Years of Motoring, 80.

${ }^{71}$ Southland Times, 8 September 1917, 6.

${ }^{72}$ Clutha Leader [Balclutha], 18 May 1915, 3. For the great growth in heavy goods vehicle use in the 1920s, see Jenny Haworth, Road's the Mode: The Story of New Zealand's Road Transport Industry (Christchurch: Wily Publications for the E. J. Brenan Memorial Trust, 2013), 18.

${ }^{73}$ NZPD 177 (1916), 381, col. 1.

${ }^{74}$ NZPD 138 (1906), 133, col. 2.

${ }^{75}$ Wanganui Herald, 27 October 1908, 2; the chairman of the Southland Motor Association became mayor of Invercargill in 1921. See Hocken AG-760/2, SMA minute book, 17: meeting of Executive Committee, 6 May 1921.

${ }^{76}$ Mataura Ensign [Gore], 21 July 1908, 2.

${ }^{77}$ Calculated from Stone's Otago and Southland Commercial, Municipal, and General Directory and New Zealand Annual, 1914, ed. John Stone (Dunedin: Stone, Son \& Co., 1914) and Toitu Otago Settlers Museum archives, Dunedin, AG-255, "Otago Motor Club List of Members season 1915/16."

${ }^{78}$ Calculated from Stone's Directory, 1924 and Hocken 95-056 Box 88/2, OMC members subscription register.

${ }^{79}$ Dunedin City Council Archives, CE 2/2/9 Mot-Mc 1915-1918, City Engineer's Office, "Motor Car," 7 February 1917.

${ }^{80}$ Southland Times, 8 May 1920. The Internal Affairs Department was responsible for most matters affecting motorists until the Department of Transport was set up in 1929.

${ }^{81}$ The New Zealand Motor Owner 2, no. 9 (15 August 1930): frontispiece.

${ }^{82}$ NZPD 225 (1930), 73, col. 1.

${ }^{83}$ The Motorist 6, no. 12 (10 October 1929): 3. Ward's predecessor Gordon Coates had given similarly short shrift to a deputation from road hauliers complaining about taxation in 1928: see Haworth, Road's the Mode, 22.

${ }^{84}$ McCrystal, 100 Years of Motoring, 21, 23-24, 26.

${ }^{85}$ NZPD 122 (1902), 141, col. 1.

${ }^{86}$ NZPD 122 (1902), 141, col. 1-2; 142, col. 1; 145, col. 1.

${ }^{87}$ Tranter, "The History of the Haste-Wagons," 850.

${ }^{88}$ Knott, "Speed, Modernity and the Motor Car," 233-34.

${ }^{89}$ NZPD 132 (1905), 522, col. 1-2.

${ }^{90}$ NZPD 138 (1906), 137, col. 2.

${ }^{91}$ NZPD 136-37 (1906), 667, col. 2; 138 (1906), 130, col. 1.

${ }^{92}$ British Parliamentary Papers, Cd. 3080; Tranter, "The History of the Haste-Wagons," 850; Knott, "Speed, Modernity and the Motor Car," 235.

${ }^{93}$ NZPD 137 (1906), 668, col. 2; see also for New South Wales in 1909 Knott, "Speed, Modernity and the Motor Car," 237-38.

${ }^{94}$ NZPD 139 (1907), 627, col. 1-2; NZPD 140 (1907), 572, col. 2; see also Mom, Atlantic

Automobilism, 27, 324.

${ }^{95}$ NZPD 140 (1907), 573, col. 1.

${ }^{96}$ Knott, "Speed, Modernity and the Motor Car," 238.

${ }^{97}$ Evening Post [Wellington], 24 September 1936, 10.

${ }^{98}$ NZPD 138 (1906), 131, col. 1.

${ }^{99}$ Tranter, "The History of the Haste-Wagons," 872-73.

${ }^{100}$ NZPD 138 (1906), 132, col. 1-2; 135, col. 1.

${ }^{101}$ NZPD 164 (1913), 438, col. 1.

Journal of New Zealand Studies NS27 (2018), 130-146

https://doi.org/10.26686/jnzs.v0iNS27.5180 
${ }^{102}$ NZPD 168 (1914), 804, col. 1.

${ }^{103}$ NZPD 168 (1914), 741, col. 1-2; 178 (1917), 515, col. 2; 517, col. 1.

${ }^{104}$ Members of the Taxi Association were invited to join the Southland Motor Association in 1921:

Hocken AG-760/2, SMA minute book, 12, 25 February 1921. From 1924, the Master Carriers and

Customs Agents Federation represented the interests of heavy goods vehicle operators: Haworth, 20

ff.

${ }^{105}$ Southland Times, 8 November 1920, 4.

${ }^{106}$ NZPD 184 (1919), 1014, col. 2.

${ }^{107}$ Evening Post, 2 October 1919, 6.

${ }^{108}$ NZPD 191 (1921), 541, col. 2; 547, col. 2; 557, col. 2.

${ }^{109}$ NZPD 198 (1922), 483, col. 1.

${ }^{110}$ NZPD 198 (1922), 486, col. 1.

${ }^{111}$ McCrystal, 100 Years of Motoring, 96-97.

${ }^{112}$ NZPD 198 (1922), 502, col. 2. "Joy-riding" is used here in the sense of motoring for pleasure, and does not imply any illegal activity.

${ }^{113}$ NZPD 198 (1922), 712, col. 1.

${ }^{114}$ Hocken AG-760/2, SMA minute book, 39: unidentified newspaper cutting [Southland News (?), c. August 1922].

115 The New Zealand Motor Owner 1, no. 5 (15 April 1929), 3.

116 James A. Dunn, "The Importance of Being Earmarked: Transport Policy and Highway Finance in Great Britain and the United States," Comparative Studies in Society and History 20, no.1 (1978): 3637, 42-43; Plowden, The Motor Car and Politics, 183-213.

${ }^{117}$ Northern Advocate [Whangarei], 17 September 1929, 7; The Motorist 6, no. 12 (10 October 1929): 3.

${ }^{118}$ New Zealand Herald, 23 July 1931, 10.

${ }^{119}$ New Zealand Historical Bills, No. 71-4. "Motor-Vehicles Bill. Explanatory Memorandum." New Zealand Legal Information Institute databases: nzlii.org/nz/legis/hist_bill

${ }^{120}$ NZPD 204 (1924), 823, col. 1; 215 (1927), 457, col. 1.

${ }^{121}$ Adopted in 1911: "Coat of Arms," in A. H. McClintock (ed.), An Encyclopaedia of New Zealand (Wellington: R. E. Owen, Government Printer, 1966). 